\title{
Inner ear pathology and loss of hearing in estrogen receptor- $\beta$ deficient mice
}

\author{
Rusana Simonoska, Annika E Stenberg, Maoli Duan', Konstantin Yakimchuk², \\ Anders Fridberger ${ }^{1}$, Lena Sahlin ${ }^{3}$, Jan-Åke Gustafsson ${ }^{2,4}$ and Malou Hultcrantz \\ Department of Otorhinolaryngology, Karolinska Institutet and Karolinska University Hospital, 17176 Stockholm, Sweden \\ ${ }^{1}$ Center for Hearing and Communication Research, Karolinska Institutet, 17176 Stockholm, Sweden \\ ${ }^{2}$ Department of Biosciences and Nutrition, Karolinska Institutet, NOVUM, 14186 Huddinge, Sweden \\ ${ }^{3}$ Department of Woman and Child Health, Karolinska Institutet and Karolinska University Hospital, 17176 Stockholm, Sweden \\ ${ }^{4}$ Department of Biology and Biochemistry, Center for Nuclear Receptors and Cell Signalling, University of Houston, Houston, Texas 77 204, USA \\ (Correspondence should be addressed to R Simonoska; Email: rusana.simonoska@karolinska.se)
}

\begin{abstract}
There are well known differences between males and females in hearing. In the present study, the role of estrogen receptor- $\beta$ (ER- $\beta$; listed as ESR 2 in the MGI Database) in hearing was investigated by comparing hearing and morphology of the inner ear in ER- $\beta$ knock-out mice $\left(E R-\beta^{-/-}\right.$) with that of wild-type (WT) littermates. Hearing was analyzed with auditory brainstem response audiometry at 3 and 12 months. The ER- $\beta^{-1-}$ mice were deaf at 1 year of age, and the morphological analysis showed absence of hair cells and loss of the whole organ of Corti initiated in the basal turn of the cochlea. Furthermore, in ER- $\beta^{-/-}$, but not in WT mice, the spiral ganglion was lacking many of its neurons.
\end{abstract}

Immunostaining showed the presence of both ER- $\alpha$ (listed as ESR1 in the MGI Database) and ER- $\beta$ in the nuclei of some neurons in the inner ear in WT mice, but no ER- $\beta$ was found in the ER- $\beta^{-1-}$ mice as expected. ER- $\alpha$ staining was predominant in the nuclei of large neurons and ER- $\beta$ in nuclei of small neurons and fibroblasts. These results reveal that both ERs are present in the inner ear at specific localizations suggesting subtype-specific functions. It is concluded that ER- $\beta$ is important for the prevention of agerelated hearing loss. These findings strengthen the hypothesis that estrogen has a direct effect on hearing functions.

Journal of Endocrinology (2009) 201, 397-406

\section{Introduction}

Hearing loss appears to be more profound (more severe hearing loss at high frequencies) in elderly human males than females. This sex difference cannot only be explained by anatomical variations or occupational noise (Jonsson et al. 1998). The hormone estradiol-17- $\beta$ is thought to play an important role as estrogen receptors (ERs) are present in the inner ear at locations important for sound transmission (Stenberg et al. 1999). Women at menopause with hormonal replacement therapy have slightly better hearing than nonsubstituted women (Kilicdag et al. 2004), and it is well documented that in auditory brainstem response (ABR) audiometry, women have shorter latencies than men (Jerger $\&$ Hall 1980). In addition, women with Turner syndrome (total or partial loss of one $\mathrm{X}$ chromosome) who are biologically estrogen deficient have longer ABR latencies and an early age-related hearing loss (Hultcrantz et al. 1994, Gungor et al. 2000). The relationship between estrogen and hearing is also obvious in non-mammalian vertebrates. For instance, in the midshipman fish (Porichthys notatus) it has been shown that the degree of temporal encoding of auditory frequencies is not a fixed trait, but has a steroid (estrogen and testosterone) dependent plasticity relevant for special signals during the seasonal breeding periods (Sisneros et al. 2004). Despite the evidence of a protective effect of estrogen, there are case reports that hormone replacement therapy and oral contraceptive use can lead to acute sudden deafness (Hanna 1986, Strachan 1996). Contradictory effects of estrogen have been observed in several systems in the body and are partly due to the fact that estrogen action depends on the balance between activation of two receptors, (ER- $\alpha$; listed as ESR1 in the MGI Database) and (ER- $\beta$; listed as ESR2 in the MGI Database) which in some situations, can oppose each other's actions (Kushner et al. 2000).

Most elderly people suffer from progressive loss of hearing, which is due to genetic and environmental factors as well as disease (for review, see (Ben-Yosef \& Friedman 2003, Nance 2003)). Genetic factors are responsible for at least half of all cases of profound congenital deafness, with mutations in the connexin 26 gene accounting for the majority of all cases (Kudo et al. 2003). 
The connection between hearing and ERs is not fully understood and very few studies on this topic are available at present. In young (3 months) ER- $\beta$ knock out mice (BERKO or ER- $\beta^{-1-}$ ), the inner ear appeared to be normal, except for swollen afferent nerve endings (Stenberg et al. 2002), and when exposed to acoustic trauma these mice were more vulnerable to hearing loss than were wild-type (WT) littermates (Meltser et al. 2008). It is also known that in the brain of the ER- $\beta^{-/-}$mice, with increasing age, neuronal loss was observed (Wang et al. 2001). The aim of the present study was to investigate if neuronal cells in the inner ear (spiral ganglion) degenerate in the same manner in the absence of ER- $\beta$. The effect of aging on hearing and inner ear morphology in female ER- $\beta^{-1-}$ mice (3 and 12 months) was investigated. In addition, immunohistochemical assessment of ER- $\alpha$ and ER- $\beta$ in the inner ear was performed to evaluate receptor expression and distribution over time in $\mathrm{ER}-\beta^{-1-}$ mice and their WT littermates.

\section{Materials and Methods}

\section{Animals}

The ER- $\beta^{-1-}$ mice were created from two inbred mouse strains, C57BL/6J and J129. The ER- $\beta^{-1-}$ colony was maintained with heterozygous breeding after backcrossing ER $-\beta^{+/-}$mice with C57BL/6J mice from Jackson Laboratories (Bar Harbor, ME, USA) for more than 11 generations (Krege et al. 1998). Comparisons were made between ER$\beta^{+/+}(\mathrm{WT})$ and ER $-\beta^{-/-}$littermates. Ten ER- $\beta^{-/-}$and 10 WT female mice were used in a longitudinal study for auditory brainstem response (ABR) measurements. Other methods used in this study were: morphology, immunohistochemistry, and immunofluorescence (double) staining. In order to correlate the morphological findings with ABR results at 3 and 12 months of age, an additional 21 mice were added to the study (12 ER $-\beta^{-1-}$ mice and $\left.9 \mathrm{WT}\right)$.

All mice were genotyped using PCR with DNA extracted from their tails at 2 weeks of age in order to determine whether they were WT or ER- $\beta^{-/-}$.

The animals were housed in a controlled environment at $20{ }^{\circ} \mathrm{C}$ with an illumination schedule of $12 \mathrm{~h}$ light: $12 \mathrm{~h}$ darkness each day. Standard pellet food and water were provided ad libitum. The care and use of the animals reported in this study were approved by the Animal Care Committee in Stockholm, Sweden.

\section{Auditory thresholds}

To analyze hearing (auditory capacity), 10 mice in each group were tested with $\mathrm{ABR}$ at 3 and 12 months of age. The method for ABR measurements has been described earlier by Duan \& Canlon (2001). After anaesthetizing the mouse with an i.p. injection of ketamine $(50 \mathrm{mg} / \mathrm{kg})$ and xylazine $(10 \mathrm{mg} / \mathrm{kg})$, responses to sound stimuli were recorded with three subcutaneously placed stainless-steel needle electrodes. Body temperature of the animal was maintained at $38^{\circ} \mathrm{C}$ with an isothermic heating pad. The stimulus signal was generated through Tucker-Davis (Alachua, FL, USA) equipment controlled by a computer and delivered by an earphone sealed to the ear channel via an ear tube. The tested frequencies were from $6 \cdot 3$ to $40 \mathrm{kHz}$. The stimuli consisted of a band-pass filtered single full sine wave and the symmetrical signal was filtered with a one-third-octave filter (Bruel \& Kjaer type 1612). The evoked response was amplified 100000 times and averaged (2048 sweeps in each run) in real-time. Stimuli were presented at intensities well above threshold and then decreased in 10-dB steps until the ABR waves disappeared. Threshold was defined as the lowest intensity $(\mathrm{dB})$ at which a measurable $\mathrm{ABR}$ wave was seen in two averaged runs. The limit of the equipment for the test frequencies is: $6.3 \mathrm{kHz}$ at $110 \mathrm{~dB}$ SPL; $12.5 \mathrm{kHz}$ at $135 \mathrm{~dB}$ SPL; $20.0 \mathrm{kHz}$ at $135 \mathrm{~dB}$ SPL; $40 \mathrm{kHz}$ at $95 \mathrm{~dB}$ SPL. When no hearing was measurable at these frequencies, a value $5 \mathrm{~dB}$ over the limit of the equipment was used in the statistical analysis. Mean and S.D. were calculated at 3 and 12 months. The electric response was generated along the brainstem auditory pathway, and the different waves represent activity in the relays from the cochlea to the inferior colliculus. Five wave peaks are usually registered and represent potentials elicited from the eighth nerve, the nucleus cochlearis, contra lateral superior olivary nucleus, the contra lateral colliculus inferior, and an area in-between the superior olive and colliculus inferior. Latencies of ABR responses are measured in milliseconds from the stimuli to the first peak (peak I) and also between peaks I and III.

\section{Tissue collection}

The mice were given an overdose of ketamine and xylazine and then decapitated. Immediately after each animal was decapitated, the temporal bones were removed.

The right temporal bone of each mouse was fixed in $2 \%$ glutaraldehyde and prepared according to standard methods for morphological analysis (embedded in JB-4 plastic) with light microscopy. The left temporal bone was fixed in $4 \%$ paraformaldehyde; the apical portion of the bony cochlea was opened and the oval and round windows were perforated. The cochlea was gently perfused with $4 \%$ paraformaldehyde in PBS ( $\mathrm{pH}$ 7.4) by a pipette in order to allow the fixative to reach the whole cochlear tissue. The cochlea was rinsed in PBS and the bone dissected. Specimens were left in $4 \%$ paraformaldehyde in PBS for $1 \mathrm{~h}$. Specimens were then decalcified for $\sim 2$ weeks in $0 \cdot 1 \mathrm{M}$ EDTA. When soft enough for sectioning the inner ears were embedded in paraffin. Paraffin-embedded tissues were then cut in $5 \mu \mathrm{m}$ sections, placed on positively charged glass slides (SuperFrost Plus, Menzel-Glaser, Braunschweig, Germany) and dried at $38^{\circ} \mathrm{C}$ overnight before application of immunohistochemistry and immunofluorescence procedures. 
Immunohistochemical staining of ERs

A standard immunohistochemical technique (avidinbiotin-peroxidase) was used to visualize ER- $\alpha$ and ER- $\beta$ immunostaining distribution. Two ER- $\alpha$ antibodies were used for detection of ER- $\alpha$ : monoclonal rabbit anti-human antibody ER- $\alpha$ (RM-9101), (Neomarkers, Fremont, CA, USA) and polyclonal rabbit anti-mouse antibody ER- $\alpha$ (MC-20): sc-542. A chicken anti-rat/human antibody (anti-ER- $\beta$ IgY 503; Saji et al. 2000), raised in our lab and shown to specifically recognize ER- $\beta$ and not ER- $\alpha$ was used for detection of ER- $\beta$.

For the immunostaining of ER- $\alpha$ and ER- $\beta$, paraffin sections $(5 \mu \mathrm{m})$ were dewaxed in BioClear and rehydrated through graduated ethanol to water. Antigens were retrieved by boiling tissue sections in $0 \cdot 01 \mathrm{M}$ sodium citrate buffer $(\mathrm{pH}$ 6.0 ) in a microwave oven on high power for $10 \mathrm{~min}$, followed by $20 \mathrm{~min}$ of cooling. Then samples were washed for $10 \mathrm{~min}$ in buffer $(0 \cdot 1$ M PBS ( $\mathrm{pH} 7.4)$ for ER- $\alpha$ and TBS ( $\mathrm{pH}$ 7.4) for ER- $\beta$ ). Non-specific endogenous peroxidase activity was blocked by treatment with $3 \% \mathrm{H}_{2} \mathrm{O}_{2}$ (Merck) in methanol at room temperature (RT). Subsequent to another $10 \mathrm{~min}$ wash in buffer, sections were placed in a dark, humidified chamber at RT and exposed for $30 \mathrm{~min}$ to immuno-block using normal goat serum (NGS; Santa Cruz Biotechnology, Santa Cruz, CA, USA) in PBS for ER- $\alpha$ and in TBS for ER- $\beta$. The tissue sections were then incubated with primary antibodies at $4{ }^{\circ} \mathrm{C}$ overnight (ER- $\alpha$ in PBS with NGS and for ER- $\beta$ in TBS with NGS and 1\% BSA). Both ER- $\alpha$ (RM-9101) and ER- $\beta$ antibodies were diluted 1:100, while ER- $\alpha$ antibody (MC20): sc-542 was diluted with PBS 1:200. Negative controls for ER $-\alpha$ and ER- $\beta$ were obtained by replacing the primary antibody with non-immune serum of the equivalent concentration or with primary antibodies after absorption with the corresponding antigen (ER- $\beta$ antibody was preabsorbed with ER- $\beta$ protein (Panerva, Madison, WI, USA)).

Following primary antibody binding, the sections were incubated with secondary antibodies at RT in the dark (30 $\mathrm{min}$ for $\mathrm{ER}-\alpha$ and $60 \mathrm{~min}$ for $\mathrm{ER}-\beta$ ). The secondary antibody was a biotinylated goat anti-rabbit IgG antibody (Santa Cruz Biotechnology), diluted 1:200 with NGS for ER- $\alpha$ staining; and a biotinylated goat anti-chicken IgY- $\beta$ (Santa Cruz Biotechnology), diluted 1:200 in NGS with 1\% BSA for ER- $\beta$ staining.

After washing with PBS containing 0.01\% Tween 20 (extra cleaning wash) for ER- $\alpha$ and TBS containing $0 \cdot 01 \%$ Tween 20 for $\mathrm{ER}-\beta$, the tissue sections were incubated for $30 \mathrm{~min}$ at RT with HRP-avidin biotin complex (Vectastain Elite, Vector Laboratories, Burlingame, CA, USA). The site of the bound enzyme was visualized by the application of $3,3^{\prime}$-diaminobenzidine (DAB kit, Vector). Thereafter, sections were counterstained with Mayer's hematoxylin and dehydrated before mounting with Pertex (Histolab, Gothenburg, Sweden).

The ovaries were used as positive control tissue for ER- $\beta$ and the uterus for ER- $\alpha$. A microscope (Leica, Wetzlar, Germany) connected via a video camera (Sony) to a computer using Colorvision software (Leica Qwin, Leica Imaging System, Cambridge, UK) was used to assess immunostaining.

The morphology photos were assessed with Zeiss Axioplan microscope with PixeLINK camera.

\section{Immunofluorescence staining}

In order to visualize both of the ERs at the same time in the same tissue section, the double immunofluorescence staining method was used. Double staining of ER- $\alpha$ and ER- $\beta$ in 12-month-old WT mice was performed as described by Reid et al. (2004). For staining of ER- $\alpha$, a monoclonal rabbit anti-human ER- $\alpha$ antibody (RM-9101, Neomarkers) was used, and for ER- $\beta$ a chicken anti-rat/human antibody (anti-ER- $\beta$ IgY 503, raised in our lab; see above).

Secondary antibodies were used as follows: for green fluorescence - Alexa 488 (goat anti-rabbit), Invitrogen, A11008, at dilution 1:500; for red fluorescence-Cy-5 (donkey anti-chicken), Jackson Laboratories, at dilution 1:500. Sections were visualized with a Zeiss LSM510 confocal microscope, using excitation wavelengths and filters appropriate for the fluorophores listed above. Pinhole settings were optimized for the objective lens used. All images were acquired in the sequential scanning mode, to minimize bleeding through.

\section{Quantification of spiral ganglion cell density}

A section of the mouse cochlea contains $4-5$ cross sections of the spiraling Rosenthal's canal (where the spiral ganglion is situated) at locations from base to apex. As successive sections were cut, when the mid-modiolar plane was reached (i.e. when all 4-5 cross sections of Rosenthal's canal were visible in the same section), every section ( $4 \mu \mathrm{m}$ thick) was collected, mounted on glass slides and stained with Paragon. Six consecutive mid-modiolar sections were assessed for spiral ganglion neuron (SGN) density. All neurons fulfilling the size and shape criteria to be considered large, type I, SGN's (i.e. cell diameter $8-20 \mu \mathrm{m}$ with a nucleus $3-6 \mu \mathrm{m}$ in diameter) within each profile of Rosenthal's canal were counted. The outline of the Rosenthal's canal profile was traced (using Sigma ScanPro 4 software) to estimate the area. The SGN profile density was then expressed as the number of SGN profiles per $10000 \mu^{2}$. A total of six cross-sections of the Rosenthal's canal, at the base of the cochlea, were analyzed in each animal. Four animals in each age-group were examined.

\section{Statistical methods}

The purpose of this study was to investigate whether there is a difference in hearing threshold (dB SPL) between ER- $\beta^{-/-}$ and WT mice at the test frequencies $6 \cdot 3,12 \cdot 5,20$, and $40 \mathrm{kHz}$ at 3 and 12 months.

The data were analyzed using linear mixed models which is a more flexible approach than the classical method of repeated measures ANOVA (Fitzmaurice et al. 2004). ANOVA has the shortcomings of having strict assumptions, such as equal 
variance across groups, equal variance at each repeated measure and equal dependence between pairs of repeated measures. These assumptions can be relaxed by using the more flexible framework of the 'Linear Mixed Models'. The dependence, due to repeated measures made on the same subject (animal), can be modeled by estimating the covariance/correlation between repeated measures. To avoid data driven results, restrictions on the covariances/correlations are usually performed, and a parsimonious model is estimated. To decide which method to use, several information criteria have been proposed by the statistical literature. In the analyses performed in this paper, the corrected Akaike's information criteria (CAIC) was used (Akaike 1974).

The S.E.M. from the analysis were utilized for performing one simple $t$-test of the difference between the mean equipment limits of the two mouse strain groups (WT and ER $-\beta^{-/-}$) at the various level of $\mathrm{kHz}$. The equipment limits were: $6.3 \mathrm{kHz}$ at $110 \mathrm{~dB}$ SPL, $12.5 \mathrm{kHz}$ at $135 \mathrm{~dB}$ SPL, $20 \mathrm{kHz}$ at $135 \mathrm{~dB}$ SPL, and $40 \mathrm{kHz}$ at $95 \mathrm{~dB}$ SPL. The linear mixed models approach was used to evaluate the effect of $\mathrm{kHz}$ group and mouse strain on the threshold (dB SPL). CAIC revealed dependence within animals with no restrictions (unstructured). Hence, the degree of dependence between each pair of $\mathrm{kHz}$ classes was estimated and the variance was assumed to be unequal across the classes. In the analysis, an interaction term, 'kHz group by mouse strain', was added to the model for testing whether or not the differences in the threshold (dB SPL) between WT and ER- $\beta^{-/-}$mice were the same regardless of $\mathrm{kHz}$ level.

Cook's distance, normality plots and various residual plots were used to evaluate the fitted models. Cook's distance is a measure of the influence of the parameter that estimates a single observation. $P$ values $<0 \cdot 05$ were used as significant results.

\section{Results}

\section{Hearing}

The 3-month-old mice varied in hearing threshold (dB SPL) in both groups; thus, the analysis could include the mouse strain group in the fitted statistical model. At this age, there was no statistical difference $(P>0 \cdot 05)$ between ER- $\beta^{-1-}$ mice $(n=10)$ and their WT littermates $(n=10)$ in ABRs (Fig. 1A). Hearing thresholds in WT mice changed with age in a similar manner to that previously reported for C57BL/6J mice with a progressive hearing loss (Li \& Hultcrantz 1994).

The measured values of hearing threshold (dB SPL) did not vary in the 12 -month-old ER- $\beta^{-1-}$ mice due to deafness, and they were omitted from the analysis. In the 12-month analysis, the CAIC suggests that the dependence within animals was the same between $\mathrm{kHz}$ classes, but with an unequal variance in each $\mathrm{kHz}$ class (heterogeneous compound symmetry). The ER- $\beta^{-1-}$ mice had a severe hearing loss exceeding that of the WT littermates, which resulted in deafness when the mice were 12 months of age. By 12 months

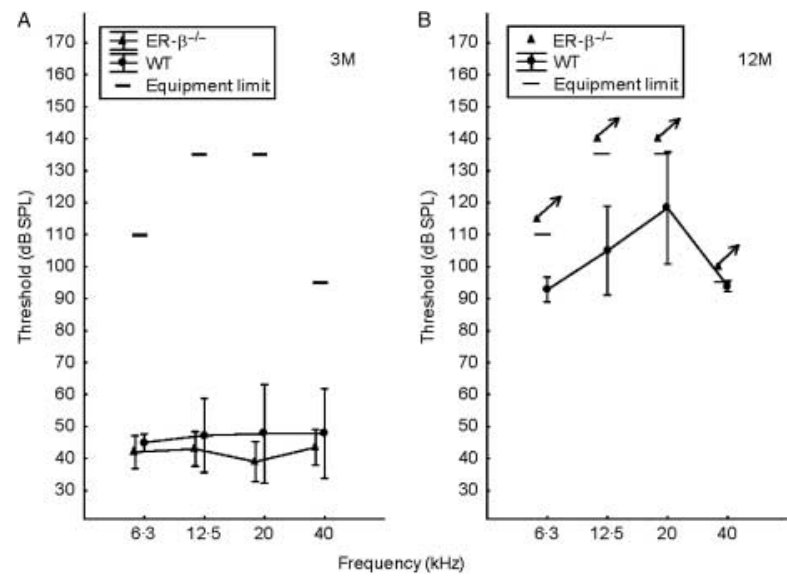

Figure 1 Auditory brainstem response (ABR) audiometry from WT and $E R-\beta^{-1-}$ mice at the age of (A) 3 months (3M), and (B) 12 months (12M). The diagrams show mean hearing thresholds with S.D. for the wild-type (black circles) and ER- $\beta^{-1-}$ (black triangles) mice. At 12 months of age, ER- $\beta^{-1-}$ mice are deaf and the hearing loss exceeds the limit of the equipment (arrows indicating no measurable threshold).

of age, hearing in ER- $\beta^{-/-}$mice was not measurable, and these mice were considered deaf (Fig. 1B). This difference in hearing thresholds between the WT and ER- $\beta^{-/-}$mice at 12 months was statistically significant $(P<0 \cdot 05)$ for all tested frequencies showing a hearing loss in the ER $-\beta^{-/-}$mice.

When the latencies were calculated there were no differences, either with regard to the first peak or between peaks I and III, between the two genotypes of 3-month-old mice. In WT mice at 3 months of age, the latencies were shorter than in mice at 12 months. No latencies could be calculated for the ER- $\beta^{-/-}$mice at 12 months, since they were deaf and no ABR waves were measurable (i.e. the hearing loss exceeded the limit of the equipment).

\section{Morphology}

At 3 months of age, the inner ear morphology of ER- $\beta^{-/-}$ mice appeared to be indistinguishable from WT mice. The organ of Corti had a normal shape containing inner (IHC) and outer (OHC) hair cells and an open tunnel of Corti (Fig. 2A). Hair cells and spiral ganglion cells, both large and small (Fig. 2B), were present in all cochlear turns.

At 12 months of age, in ER- $\beta^{-/-}$mice, in the basal turns, the organ of Corti showed a flat epithelium. No IHCs and OHCs were observed (Fig. 2C). There was a major loss of all hair cells in the basal turns, corresponding to an almost total loss of ganglion cells at the same level (Fig. 2C and D). Loss of hair cells was also found in the middle and to a lesser extent in the apical turn. In both locations, the corresponding ganglion cells were present. There was also loss of hair cells and spiral ganglion cells in the 12-month-old WT mice, especially in the basal turn of the cochlea, but the loss was not as extensive as that seen in the ER- $\beta^{-1-}$ mouse (Fig. $2 \mathrm{E}$ and F). 

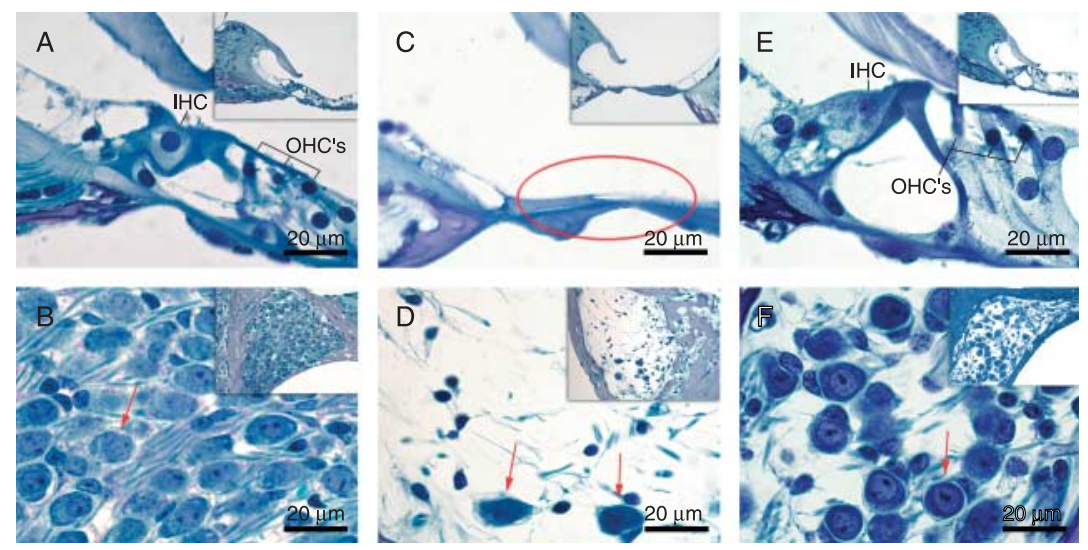

Figure 2 Morphological photos from: the basal turn of the cochlea in a 3-month-old $\mathrm{ER}-\beta^{-1-}$ mouse (A and B); 12 -month-old ER- $\beta^{-1-}$ mouse (C and D), and 12-month-old WT mouse (E and F). (A) Shows a normal organ of Corti with intact inner hair cell (IHC) and three outer hair cells $(\mathrm{OHCs})$ and in (B) the spiral ganglion is filled with spiral ganglion cells (red arrow). (C) Shows the organ of Corti in a 12-month-old ER- $\beta^{-1-}$ mouse that has degenerated, resulting in a flat epithelium (red circle) and in (D), there is an extensive loss of ganglion cells in the spiral ganglion, with a red arrow indicating the few cells left. (E) Shows fairly normal organ of Corti in 12-month-old WT mouse and (F) shows the spiral ganglion with loss of spiral ganglion cells (arrow), but in comparison with 12 -month-old ER- $\beta^{-\prime-}$ mice (D) the loss is not as extensive.

\section{Quantification of spiral ganglion cell density}

The presence of SGN in the base of the cochlea, at 3 and 12 months of age in ER- $\beta^{-1-}$ and WT mice was measured by calculating the cell density in sections of the Rosenthal's canal at different locations along the length of the cochlea. The SGN profile density (d) is expressed as the number of SGN profiles per $10000 \mu^{2}$.

The density of spiral ganglion neurons in the basal part of the cochlea at 12 months of age was significantly higher in WT mice compared with ER- $\beta^{-\prime-}$ mice. There was no difference in SGN density in 3-month-old mice (Table 1). Both groups had similar high densities in the apex at both 3 and 12 months. At 12 months of age, the mean density, in the base of the cochlea, in the WT mice was about $2 \cdot 7$ times higher than in the ER- $\beta^{-\prime-}$ mice.

\section{Immunofluorescence and immunohistochemistry}

WT Three-month-old WT mice showed the same pattern of ER- $\alpha$ staining as described earlier in CBA-mice (Stenberg et al. 1999), but with the new antibodies developed for ER- $\beta$

Table 1 Spiral ganglion neuron (SGN) density in the wild-type (WT) and estrogen receptor $\beta\left(\right.$ ER- $\left.\beta^{-\prime-}\right)$ mice. Density profile expressed as the number of SGN profiles per $10000 \mu \mathrm{m}^{2}$. At 12 months of age, the SGN density is significantly lowered in ER- $\beta^{-/-}$mice

$\begin{array}{llll} & \text { WT } & & \text { ER- } \boldsymbol{\beta}^{- \text {I- }} \\ \text { Three months } & 44 \cdot 80 \pm 0 \cdot 24 & & 45 \cdot 12 \pm 0 \cdot 24 \\ \text { Twelve months } & 16 \cdot 46 \pm 6 \cdot 34 & & 6 \cdot 20 \pm 2 \cdot 93\end{array}$

Wild-type (WT) mice; estrogen receptor $\beta$ deficient $\left(E R-\beta^{-/-}\right)$mice. (used in the present study) there were some minor differences in the organ of Corti. The present study showed no staining of IHCs, but weak staining of OHCs and pillar cells compared with the study done by Stenberg et al. (1999). In the spiral ganglion, both at 3 and 12 months, large ganglion cells were preferentially stained with ER- $\alpha$ and small ganglion cells with ER- $\beta$.

In 12-month-old WT mice, immunohistochemical and double immunofluorescence analysis showed presence of ER- $\alpha$ in large spiral ganglion cells and weak ER- $\alpha$ staining in stria vascularis (Fig. 3) and no staining in organ of Corti.

ER- $\beta$ was generally present in more nuclei in the inner ear than ER- $\alpha$. ER- $\beta$ was especially abundant in cells with smaller nuclei in the spiral ganglion. Also, ER- $\beta$ was abundant in the limbus, stria vascularis, and the spiral ligament, harboring fibroblasts and fibrocytes (Fig. 3). When ER- $\alpha$ and ER- $\beta$ were visualized in the same section, there was some co localization, indicating that the two ERs are sometimes present in the same cells (Fig. 3C, F, and I).

ER- $\boldsymbol{\beta}^{-/-}$mice ER- $\boldsymbol{\alpha}$ nuclear staining in the inner ear of 3-month-old ER- $\beta^{-/-}$mice (Fig. 4A-D) and WT littermates was indistinguishable from the normal pattern previously described in CBA mice (Stenberg et al. 1999). As shown in Fig. 4A, in the spiral ganglion, ER- $\alpha$ staining was seen in the large spiral ganglion cells. As expected, no ER- $\beta$ staining was detectable in the inner ear of $\mathrm{ER}-\beta^{-/-}$mice (Fig. 4B). In the organ of Corti, there was ER- $\alpha$ staining in the nuclei of IHCs and supporting cells, and weaker staining in the OHCs (Fig. 4C) and the marginal and basal cells of stria vascularis (Fig. 4D). Some nuclei in the spiral ligament were stained. 

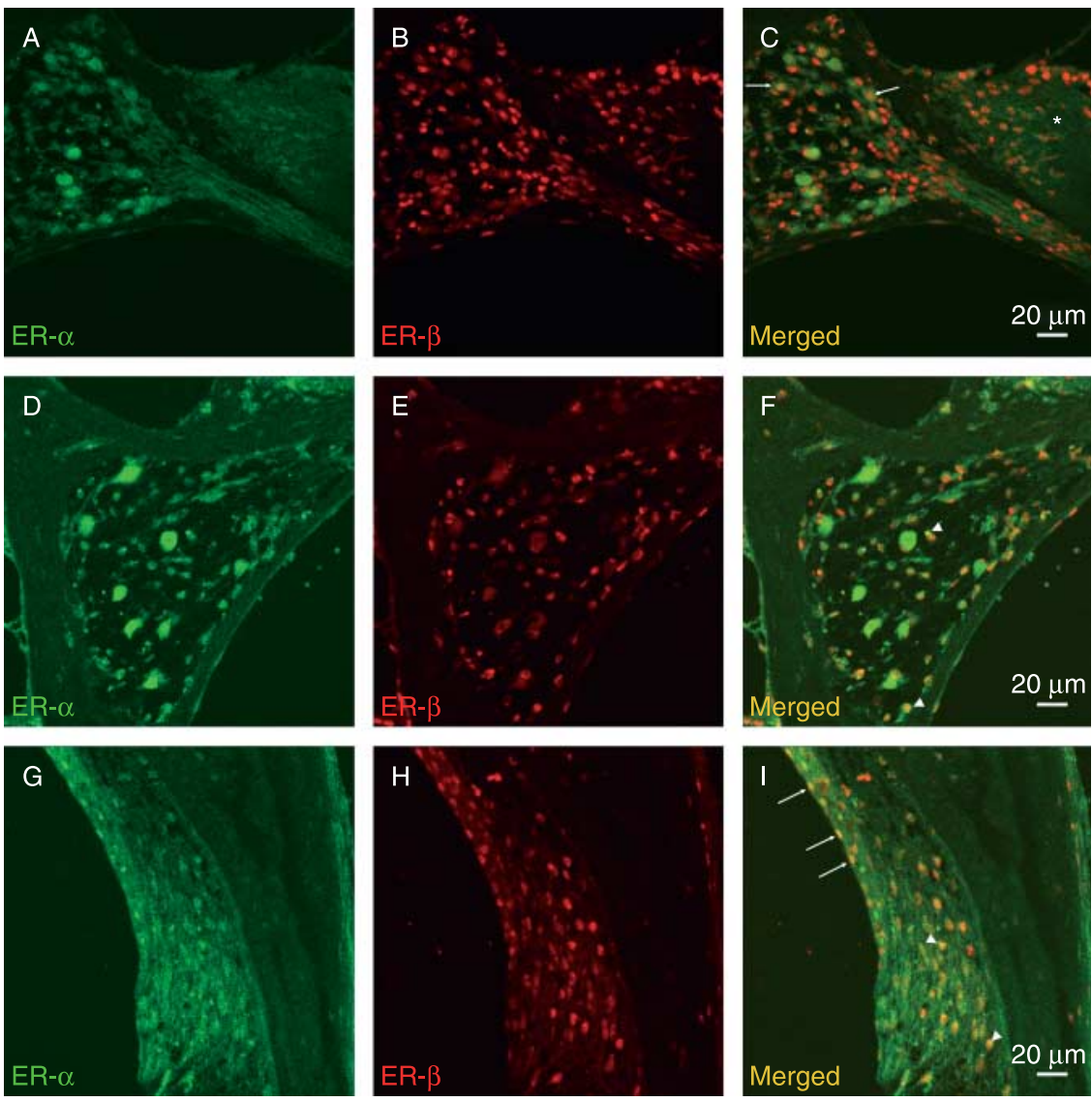

Figure 3 Double immunofluorescence staining of the cochlea in a 12-month-old WT mouse. ER- $\alpha$ was stained green (A, D, and $G)$, and ER- $\beta$ was stained red (B, E, and $H)$. (A-C) Show the middle/apical turn of the spiral ganglion; (D-F) show the basal turn of the cochlea; and (G-I) show the stria vascularis. In the merged sections $(\mathrm{C}, \mathrm{F}$, and $\mathrm{I}$ ) there is co-localization (arrows and arrowheads) of ER- $\alpha$ and ER- $\beta$, indicating that both subgroups of estrogen receptors are present in the same cells. In (C), a predominantly positive staining for ER- $\beta$ in the limbus (asterix) and in the small cells (neurons) of the spiral ganglion is seen, with co-localization of both receptors in the large cells/neurons in the spiral ganglion (arrows). In (I), co-localization of both receptors is seen in the marginal cells (arrows) of stria vascularis, and in the fibrocytes (arrowheads) in the spiral ligament.

In 12-month-old ER- $\beta^{-/-}$mice in the basal turn of the cochlea, nuclei that stained positive for ER- $\alpha$ were seen in the few remaining spiral ganglion cells, but no staining was detected in the organ of Corti which was degenerated (flat epithelium) or the stria vascularis (Fig. 5A-C).

However, in the apical turn of the cochlea, there was ER- $\alpha$ staining in the spiral ganglion, weak staining in stria vascularis, but no staining in the organ of Corti, except for weak staining in the supporting cells (Fig. 5D-F).

\section{Discussion}

The loss of hearing in ER- $\beta^{-/-}$knock-out mice shown in this study indicates that ER- $\beta$ is important in maintaining hearing. At 1 year of age, ER- $\beta^{-1-}$ mice were deaf. The importance of ER- $\beta$ in hearing is not fully understood, and few prior studies are available. In a recent study by Meltser et al. (2008), ER- $\beta$ was found to protect against acoustic trauma. The authors suggested that ER- $\beta$ acts in conjunction with brain-derived neurotrophic factor (BDNF), which is known to protect hair cells and spiral ganglion cells against acoustic trauma and ototoxic substances. In that study, the young knock-out mice were investigated regarding the sensitivity to acoustic trauma after treatment with ER- $\beta$-selective agonists, showing that an increase in the protective BDNF reduced the sensitivity to acoustic trauma for mice deficient of aromatase (aromatase knock-out mice) and in WT mice. The role of ER $-\alpha$ in hearing is, however, not conclusive, but young ER $-\alpha$ deficient (ERKO or ER- $\alpha^{-/-}$) mice are not as sensitive to acoustic trauma as the young ER- $\beta^{-/-}$mice are. ER- $\alpha$ alone does not seem to be sufficient to maintain normal hearing in ER- $\beta^{-/-}$mice. These findings also emphasize the importance of ER- $\beta$ in hearing. 

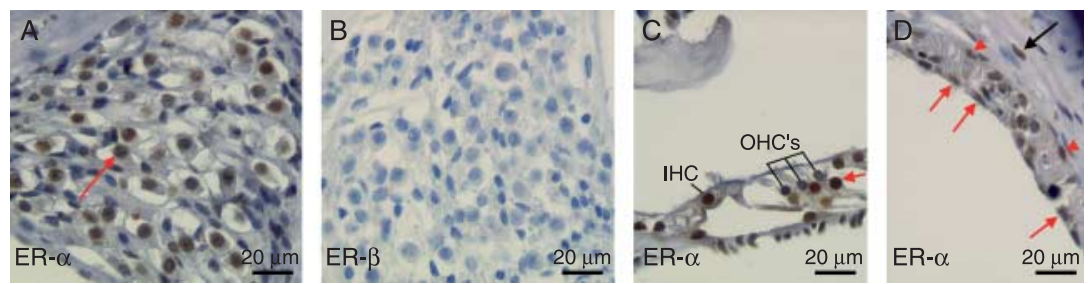

Figure 4 Immunohistochemical ER- $\alpha$ and ER- $\beta$ staining in a 3-month-old ER- $\beta^{-1-}$ mouse. Brown color indicates positive staining. (A) Shows positive ER- $\alpha$ staining of the large cells (red arrow) in the spiral ganglion, and in (B), as expected, no staining of ER- $\beta$ in the spiral ganglion is seen. (C) Shows ER- $\alpha$-positive staining in the organ of Corti, namely in the inner hair cell (IHC) and the supporting cells (red arrow), but a weaker ER- $\alpha$ staining in some of the outer hair cells (OHCs). (D) ER- $\alpha$ staining in stria vascularis, shows positive marginal cells (red arrows) and basal cells (arrowheads), and also positive fibrocytes in the spiral ligament (black arrow).

In the pregnant and developing rat, both ERs (ER- $\alpha$ and $E R-\beta)$ are up- or down-regulated in the inner ear depending on the stage of maturation, development, and pregnancy, suggesting that estrogen may have effects on the cochlea during various stages in life (Simonoska et al. 2009). In accordance with these findings, there are results showing that during regeneration of the hair cells in the avian inner ear (the only animals that are known to regenerate their inner ear hair cells), multiple components of ER signaling are involved (Hawkins et al. 2007).

In the present study, the observed hearing loss and premature deafness corresponded to hair cell loss in the cochlea; the degeneration started in the basal turn and spread towards the apex. The spiral ganglion cells followed the same degeneration pattern. These areas are known from earlier studies to contain cells that normally express ER- $\beta$ (Stenberg et al. 1999). In this regard, it is interesting that many of the genes, which when mutated, cause deafness, are ER- $\beta$-regulated genes. Connexin 26 , cadherin, myosin, and procadherin 15 have been found by microarray analysis of prostate, heart, mammary gland, and lung to be underexpressed in ER- $\beta^{-1-}$ mice (Lindberg et al. 2003). Elimination of ER- $\beta$ could, therefore, be expected to be accompanied by a loss of or decrease in expression of multiple genes involved in hearing. Mutations in structural genes such as myosin (Donaudy et al. 2003, Kudo et al. 2003), usherin (Eudy et al. 1998, Pennings et al. 2002), and aquaporin (Mhatre et al. 2002) also result in deafness.
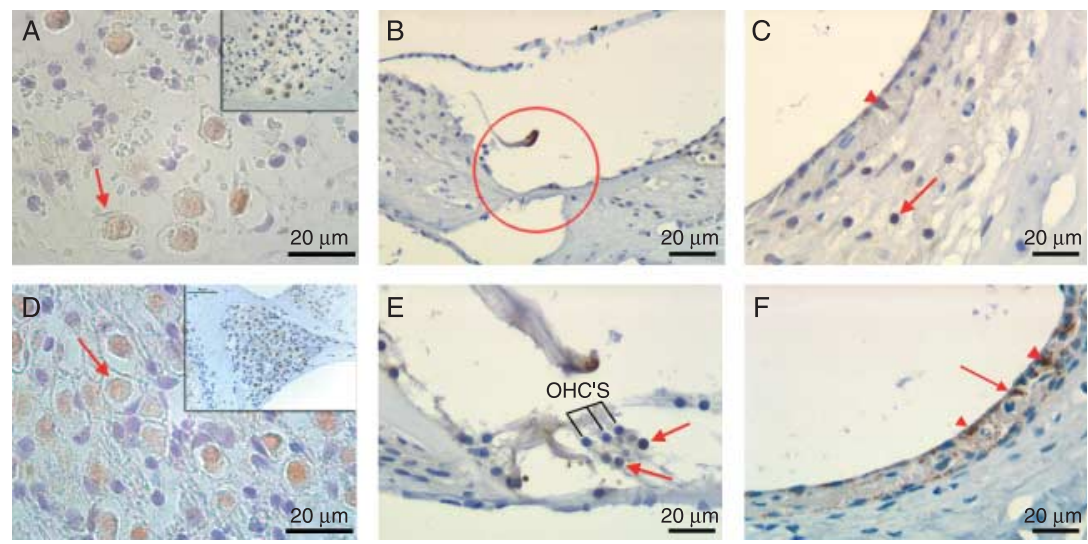

Figure 5 Immunohistochemical ER- $\alpha$ staining of the inner ear of a 12 -month-old ER- $\beta^{-/-}$ mouse. Brown color indicates positive staining. In the basal turn of the cochlea (A-C), (A) shows only a few large cells/neurons (red arrow) remaining in the spiral ganglion stained with ER- $\alpha$, and (B) shows that the organ of Corti is missing, resulting in a flat epithelium (red circle). In (C), a weak staining of fibroblast cells (arrow) is seen in the spiral ligament, but no visible ER- $\alpha$ staining in the stria vascularis. The cell in the stria vascularis showing a weak brown corn-like staining is a melanocyte (arrowhead). In the apical turn of the cochlea (D-F), (D) shows that the spiral ganglion is well preserved with positive ER- $\alpha$ staining of the spiral ganglion cells/neurons, and a seemingly normal organ of Corti $(\mathrm{E})$, but no staining of ER- $\alpha$ is seen in either inner- or outer hair cells (IHC and OHC's respectively) and very weak ER- $\alpha$ staining is seen in the supporting cells (arrows). In (F), a weak ER- $\alpha$ staining (arrow) is seen in stria vascularis, and the brown corn-like staining (arrowhead) indicates melanocytes. 
In the present study, calculated ABR latencies increased with age in WT mice, but in ER- $\beta^{-/-}$mice, the latencies at 12 months could not be calculated because the mice were deaf. Prolonged latencies indicate that there is a delay of the impulses in the cochlear nerve and in the flow of information through the central hearing pathways to the hearing centers of the brain. In normal rats, ovariectomy (i.e. removal of the endogenous estrogen production), leads to changes in ABR with prolonged latencies. These changes are reversed by estrogen replacement (Coleman et al. 1994). ER- $\beta$ is found to be expressed at high levels in the central nervous system, both in neurons and glial cells (Wang et al. 2001). In ER- $\beta^{-/-}$ mice, the degeneration of neural cell bodies in the brain is more pronounced with increasing age. At present, it is not possible to conclude whether the pathology found in the inner ear depends on a primary central retrograde degeneration resulting from loss of neurons in the central hearing cortex, or on a primary peripheral degeneration of the hair cells with a secondary degeneration of ganglion cells. Hequembourg \& Liberman (2001), have suggested that the cause of the age dependent hearing loss is a genetically programmed degeneration of the type IV fibrocytes in the spiral ligament in the C57BL/6J mouse. They hypothesize that this would cause a disturbed $\mathrm{K}+$ circulation likely followed by a chronically decreased endolymphatic potential that would lead to a threshold elevation. Hair cell degeneration would follow, and then an antegrade ganglion cell degeneration. In the Hequembourg study, a loss of hair cells and ganglion cells was found, starting in the basal turn spreading up to the apex (Hequembourg \& Liberman 2001). This theory could be applied in the present study since stria vascularis in the basal turn of the cochlea is devoid of both ERs in ER- $\beta^{-1-}$ mice at 12 months of age.

Additional factors may operate in the degeneration of structures in the inner ear of ER- $\beta^{-/-}$mice. König et al. (2008) reported that megalin, a low-density lipoprotein receptor, is present in the same cells (marginal cells) in stria vascularis as ER- $\beta$. FITC-labeled estrogen is taken up into the strial marginal cells; however, in megalin-deficient mice the uptake of FITC-labeled estrogen into strial marginal cells is reduced. In these megalin deficient mice, by the age of 3 months, a profound hearing loss already exists as well as disturbed expression of potassium channels. Megalin could therefore possibly be a candidate for binding of estrogen or ERs. This could indicate degenerative pathways in the inner ear where loss of estrogen transport could be detrimental (König et al. 2008). Based on the findings of König et al., the hearing loss in the ER- $\beta^{-/-}$mice in the present study could be explained by abnormal water/ion regulation caused by pre-mature degeneration of ER- $\beta$-deficient stria vascularis. Also the very weak expression (down-regulation) of ER- $\alpha$ in the stria vascularis in ER- $\beta^{-1-}$ mice could be another factor leading to disturbed water/ion balance with a decrease in the endocochlear potential that could also contribute to the deafness by 12 months of age in these mice. ER- $\alpha$ staining is lost in both $12-$ month-old ER- $\beta^{-/-}$and WT mice in the organ of Corti, but ER- $\alpha$ is present, although to a lesser extent, in both animal groups in the spiral ganglion (mainly in the large ganglion cells). ER- $\alpha$ staining is present in an equal manner in older mice (12 months) of both animal groups, strengthening the hypothesis that ER- $\beta$ is the main ER isoform protecting against hearing loss.

Inbred strains of mice provide unique tools for studying genetic aspects of hearing loss. The knock-out mice used in this study were created from two mouse strains, C57BL/6J and J129 mice. The C57BL/6J mouse represents one of the most commonly used mouse strains in studies on aging and audition, and its hearing loss is similar to that seen in humans (i.e., loss starts in the high-frequency region). In these mice, from their second to third month through the 12th month of life, hearing progressively declines in the highfrequency region followed by the middle and the lower frequencies (basal turn towards the apical cochlear part; Li \& Hultcrantz 1994, Idrizbegovic et al. 2003). At about 18 months of age, the C57BL/6J mice are almost deaf. The most severe hearing loss is found in the $6 \cdot 3-16 \mathrm{kHz}$ regions. Morphologically, this is presented as a severe loss of OHCs. At almost 2 years of age, the whole organ of Corti is lost (flat epithelium), the OHCs being more vulnerable than the IHCs ( $\mathrm{Li} \&$ Hultcrantz 1994). In this strain, however, no central pathways seemed to be engaged in the hearing loss. All of the severe changes that occurred by 2 years of age in the C57BL/6J mice already occurred by 1 year in the ER- $\beta^{-/-}$mice of the present study. At 1 year, the ER $-\beta^{-/-}$mice had no measurable hearing, and the organ of Corti had already a flat epithelium.

In some cases of estrogen deficiency, a progressive hearing loss in the high-frequency region has been observed, as seen in the 'Turner mouse' (missing one X-chromosome; Hultcrantz et al. 2000). These mice have no estrogen production, but a normal pattern of ERs (Stenberg et al. 2002), and their hearing loss seems to be of cochlear origin with a central component engaging the eighth cranial nerve, resembling that of the ER $-\beta^{-1-}$ mice. Since 'Turner mice' are estrogen deficient, it is not surprising that defects in these mice resemble those found in ER- $\beta^{-1-}$ mice. It is well known that women with Turner syndrome develop a progressive sensorineural hearing loss early in life (Hultcrantz et al. 1994). This syndrome is a suitable human model for the assessment of physiological processes in organs, including the ear, that have matured in a highly estrogen deficient environment.

In a clinical study in which the peripheral and central hearing functions of women with Turner syndrome were assessed, the major hearing loss was due to a peripheral cochlear degeneration (Hederstierna et al. 2009). Impairment of spatial learning is present in women with Turner syndrome and this deficiency has also been demonstrated in ER- $\beta^{-/-}$mice (Boman et al. 1998, Rissman et al. 2002). In the light of the Turner syndrome studies, the theory of the present study (i.e. ER- $\beta$ is essential for maintaining hearing functions) could be applied because of the similar pattern of the inner ear cell degeneration in the basal turn as well as premature deterioration of hearing function. 


\section{Conclusion}

We conclude that ER- $\beta$ is important for the prevention of age-related hearing loss. Thus, the hypothesis that estrogen has a direct effect on hearing functions is strengthened. From a clinical point of view, this may be valuable information when considering hormone replacement therapy in women after menopause or in those with estrogen deficiency such as women with Turner syndrome. In the future, when selective ER- $\beta$ agonists might become available for clinical use, such drugs could theoretically offer a good therapeutic intervention against hearing loss.

\section{Declaration of interest}

$\mathrm{J}-\AA \mathrm{G}$ is a shareholder and consultant for KaroBio $\mathrm{AB}$. All other authors declare that there is no conflict of interest that would prejudice the impartiality of the research reported.

\section{Funding}

This study was supported by grants from the Swedish Cancer Society, KaroBio AB, the Swedish Research Council (no 430205/3Vr, K2002-04-14235-01A, K2006-73X-20137, and K2007-63X-20398-01-3), Acta Otolaryngologica and the Stinger Foundation.

\section{Acknowledgements}

The authors wish to thank Jianxin Qiu for invaluable help with the ABRmeasurements, Britt Masironi for helpful technical assistance, and Natalie Wisniewski for editorial support.

\section{References}

Akaike H 1974 A new look at the statistical model identification. IEEE Transactions on Automatic Control 6 716-723.

Ben-Yosef T \& Friedman TB 2003 The genetic bases for syndromic and nonsyndromic deafness among Jews. Trends in Molecular Medicine 9 496-502.

Boman UW, Moller A \& Albertsson-Wikland K 1998 Psychological aspects of Turner syndrome. Journal of Psychosomatic Obstetrics and Gynaecology 19 1-18.

Coleman JR, Campbell D, Cooper WA, Welsh MG \& Moyer J 1994 Auditory brainstem responses after ovariectomy and estrogen replacement in rat. Hearing Research 80 209-215.

Donaudy F, Ferrara A, Esposito L, Hertzano R, Ben-David O, Bell RE, Melchionda S, Zelante L, Avraham KB \& Gasparini P 2003 Multiple mutations of MYO1A, a cochlear-expressed gene, in sensorineural hearing loss. American Journal of Human Genetics 72 1571-1577.

Duan ML \& Canlon B 2001 Short-term adaptation in the peripheral auditory system is related to the AMPA receptor. Acta Oto-Laryngologica 121 21-27.

Eudy JD, Yao S, Weston MD, Ma-Edmonds M, Talmadge CB, Cheng JJ, Kimberling WJ \& Sumegi J 1998 Isolation of a gene encoding a novel member of the nuclear receptor superfamily from the critical region of Usher syndrome type IIa at 1q41. Genomics 50 382-384.

Fitzmaurice MG, Laird MN \& Ware HJ 2004 Applied Longitudinal Analysis. Hoboken, NJ: John Wiley \& Sons Inc. (ISBN 0-471-21487-6).

Gungor N, Boke B, Belgin E \& Tuncbilek E 2000 High frequency hearing loss in Ullrich-Turner syndrome. European Journal of Pediatrics 159 740-744.

Hanna GS 1986 Sudden deafness and the contraceptive pill. Journal of Laryngology and Otology 100 701-706.
Hawkins RD, Bashiardes S, Powder KE, Sajan SA, Bhonagiri V, Alvarado DM, Speck J, Warchol ME \& Lovett M 2007 Large scale gene expression profiles of regenerating inner ear sensory epithelia. PLoS ONE 2 e525.

Hederstierna C, Hultcrantz M \& Rosenhall U 2009 Estrogen and hearing from a clinical point of view; characteristics of auditory function in women with Turner syndrome. Hearing Research. DOI:10.1016/j.heares.2008.11.006.

Hequembourg S \& Liberman MC 2001 Spiral ligament pathology: a major aspect of age-related cochlear degeneration in C57BL/6 mice. Journal of the Association for Research in Otolaryngology 2 118-129.

Hultcrantz M, Sylven L \& Borg E 1994 Ear and hearing problems in 44 middle-aged women with Turner's syndrome. Hearing Research 76 127-132.

Hultcrantz M, Stenberg AE, Fransson A \& Canlon B 2000 Characterization of hearing in an X,0 'Turner mouse'. Hearing Research 143 182-188.

Idrizbegovic E, Bogdanovic N, Viberg A \& Canlon B 2003 Auditory peripheral influences on calcium binding protein immunoreactivity in the cochlear nucleus during aging in the C57BL/6J mouse. Hearing Research $17933-42$.

Jerger J \& Hall J 1980 Effects of age and sex on auditory brainstem response. Archives of Otolaryngology - Head and Neck Surgery 106 387-391.

Jonsson R, Rosenhall U, Gause-Nilsson I \& Steen B 1998 Auditory function in 70- and 75-year-olds of four age cohorts. A cross-sectional and time-lag study of presbyacusis. Scandinavian Audiology 27 81-93.

Kilicdag EB, Yavuz H, Bagis T, Tarim E, Erkan AN \& Kazanci F 2004 Effects of estrogen therapy on hearing in postmenopausal women. American Journal of Obstetrics and Gynaecology 190 77-82.

König O, Ruttiger L, Muller M, Zimmermann U, Erdmann B, Kalbacher H, Gross M \& Knipper M 2008 Estrogen and the inner ear: megalin knockout mice suffer progressive hearing loss. FASEB Journal 22 410-417.

Krege JH, Hodgin JB, Couse JF, Enmark E, Warner M, Mahler JF, Sar M, Korach KS, Gustafsson JA \& Smithies O 1998 Generation and reproductive phenotypes of mice lacking estrogen receptor beta. PNAS $9515677-$ 15682.

Kudo T, Kure S, Ikeda K, Xia AP, Katori Y, Suzuki M, Kojima K, Ichinohe A, Suzuki Y, Aoki Y et al. 2003 Transgenic expression of a dominant-negative connexin26 causes degeneration of the organ of Corti and non-syndromic deafness. Human Molecular Genetics 12 995-1004.

Kushner PJ, Agard DA, Greene GL, Scanlan TS, Shiau AK, Uht RM \& Webb P 2000 Estrogen receptor pathways to AP-1. Journal of Steroid Biochemistry and Molecular Biology 74 311-317.

Li HS \& Hultcrantz M 1994 Age-related degeneration of the organ of Corti in two genotypes of mice. ORL; Journal for Otorhinolaryngology and its Related Specialties $\mathbf{5 6}$ 61-67.

Lindberg MK, Moverare S, Skrtic S, Gao H, Dahlman-Wright K, Gustafsson JA \& Ohlsson C 2003 Estrogen receptor (ER)-beta reduces ERalpharegulated gene transcription, supporting a 'ying yang' relationship between ERalpha and ERbeta in mice. Molecular Endocrinology 17 203-208.

Meltser I, Tahera Y, Simpson E, Hultcrantz M, Charitidi K, Gustafsson JA \& Canlon B 2008 Estrogen receptor beta protects against acoustic trauma in mice. Journal of Clinical Investigation 118 1563-1570.

Mhatre AN, Stern RE, Li J \& Lalwani AK 2002 Aquaporin 4 expression in the mammalian inner ear and its role in hearing. Biochemical and Biophysical Research Communications 297 987-996.

Nance WE 2003 The genetics of deafness. Mental Retardation and Developmental Disabilities Research Reviews 9 109-119.

Pennings RJ, Wagenaar M, van Aarem A, Huygen PL, Kimberling WJ \& Cremers CW 2002 Hearing impairment in Usher's syndrome. Advances in Oto-Rhino-Laryngology 61 184-191.

Reid MA, Flores-Otero J \& Davis RL 2004 Firing patterns of type II spiral ganglion neurons in vitro. Journal of Neuroscience 24 733-742.

Rissman EF, Heck AL, Leonard JE, Shupnik MA \& Gustafsson JA 2002 Disruption of estrogen receptor beta gene impairs spatial learning in female mice. PNAS 99 3996-4001.

Saji S, Jensen EV, Nilsson S, Rylander T, Warner M \& Gustafsson JA 2000 Estrogen receptors $\alpha$ and $\beta$ in the rodent mammary gland. PNAS 97 337-342. 
Simonoska R, Stenberg AE, Masironi B, Sahlin L \& Hultcrantz M 2009 Estrogen receptors in the inner ear during different stages of pregnancy and development in the rat. Acta Oto-Laryngologica. DOI:10.1080/00016480802691150.

Sisneros JA, Forlano PM, Deitcher DL \& Bass AH 2004 Steroid-dependent auditory plasticity leads to adaptive coupling of sender and receiver. Science 305 404-407.

Stenberg AE, Wang H, Sahlin L \& Hultcrantz M 1999 Mapping of estrogen receptors alpha and beta in the inner ear of mouse and rat. Hearing Research $13629-34$

Stenberg AE, Wang H, Sahlin L, Stierna P, Enmark E \& Hultcrantz M 2002 Estrogen receptors alpha and beta in the inner ear of the 'Turner mouse' and an estrogen receptor beta knockout mouse. Hearing Research 166 1-8.
Strachan D 1996 Sudden sensorineural deafness and hormone replacement therapy. Journal of Laryngology and Otology 110 1148-1150.

Wang L, Andersson S, Warner M \& Gustafsson JA 2001 Morphological abnormalities in the brains of estrogen receptor beta knockout mice. PNAS 98 2792-2796.

Received in final form 10 March 2009

Accepted 16 March 2009

Made available online as an Accepted Preprint 17 March 2009 